DOI: $10.4274 /$ jarem.galenos.2021.69775

J Acad Res Med 2021;11(2):179-86

\title{
The Role of Procalcitonin and Other Markers of Inflammation in Predicting Spontaneous Passage of Ureteral Stones
}

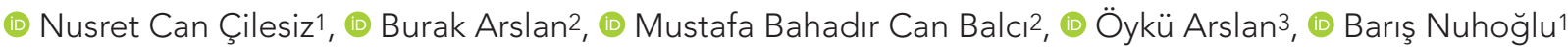 \\ ${ }^{1}$ Biruni University Faculty of Medicine, Department of Urology, İstanbul, Turkey \\ 2University of Health Sciences Turkey, Gaziosmanpaşa Training and Research Hospital, Clinic of Urology, İstanbul, Turkey \\ ${ }^{3}$ University of Health Sciences Turkey, Başakşehir Çam and Sakura City Hospital, Clinic of Hematology, İstanbul, Turkey
}

Cite this article as: Çilesiz NC, Arslan B, Balcı MBC, Arslan Ö, Nuhoğlu B. The Role of Procalcitonin and Other Markers of Inflammation in Predicting Spontaneous Passage of Ureteral Stones. J Acad Res Med 2021;11(2):179-86

\begin{abstract}
Objective: Ureteral stones are monitored for spontaneous passage in cases where there is no indication of interventional treatment. In this prospective study, we aimed to investigate the role of biochemical inflammation factors in predicting spontaneous passage.

Methods: Our study was conducted in patients who presented with ureteral stones between August and November 2016, following ethics committee approval and patient consent. The inflammatory markers [white blood cell (WBC), C-reactive protein, sedimentation, mean platelet volume, neutrophil/lymphocyte ratio, procalcitonin in serum; WBC and bacteria in urine] were recorded in 54 patients with 5-10 mm single ureteral stones and no indication for interventional treatment, and a control group of 33 volunteers with the same socio-demographic conditions. Medical expulsive therapy was applied to the case group and followed for 4 weeks. At the end of the follow-up, the case group was divided into two groups as passage $(+)$ and passage (-). The groups' data were compared statistically.

Results: Distal localization (70\% vs $37.5 \% ; p<0.05)$ was significantly higher in the passage $(+)$ group than in the passage (-). Procalcitonin (207 \pm 145.1 $\mathrm{pg} / \mathrm{mL}$ ) was significantly higher $(\mathrm{p}<0.05)$ in the passage $(-)$ group than in the passage $(+)$ group $(132.7 \pm 28.1 \mathrm{pg} / \mathrm{mL})$. In the passage $(-)$ group, the rate of leukocyturia ( $58.3 \%$ vs $20 \%$; $p<0.05)$ was higher than in the passage (+) group. A significant activity of procalcitonin value [0.805 $(0.687-0.923)$ under the curve] was observed in the separation of patients with and without passages. A significant activity of procalcitonin $160 \mathrm{pg} / \mathrm{mL} \mathrm{cut-off} \mathrm{value} \mathrm{[0.788}$ $(0.658-0.917)$ under the curve] was observed in the separation of patients with and without passages. Sensitivity was $86.7 \%$, specificity was $70.8 \%$, positive estimate was $78.8 \%$, negative estimate was $81.0 \%$.

Conclusion: Spontaneous passage in ureteral stones can be estimated by looking at serum procalcitonin levels. The receiver operating characteristic curve showed that for serum procalcitonin, the cut-off value of $160 \mathrm{pg} / \mathrm{mL}$ may have significant effectiveness. In addition, leukocyturia is also one of the factors that negatively affect spontaneous passage.
\end{abstract}

Keywords: Ureteral stone, medical expulsive therapy, follow-up

ORCID IDs of the authors: N.C.Ç. 0000-0003-2115-698X; B.A. 0000-0001-6629-5153; M.B.C.B. 0000-0003-0395-1154; Ö.A. 0000-0003-0135-2967; B.N. 0000-0001-8104-0853

Sorumlu Yazar/Corresponding Author: Nusret Can Çilesiz, E-mail: nusretcancilesiz@gmail.com
Geliş Tarihi/Received Date: 03.02.2021 Kabul Tarihi/Accepted Date: 11.06.2021

(C) Copyright 2021 by University of Health Sciences Turkey, Gaziosmanpaşa Training and Research Hospital. Available on-line at www.jarem.org 


\section{INTRODUCTION}

Urinary tract stone disease is the third most common urinary tract disease after urinary tract infection and benign prostatic hyperplasia. The lifetime rate of urinary tract stone disease is $13 \%$ for men and $7 \%$ for women. It most affects the population aged 30-60 years. The likelihood of recurrence increases over the years and reaches $50 \%$ within 5 years (1). In recent years, the spread of sedentary life and poor eating habits has increased the likelihood of urinary tract stone disease.

Urinary tract stones are most commonly detected in the kidney, while $20 \%$ are detected in ureteral localization (2). The most common cause of renal colic, one of the common problems in the emergency department, is ureteral stones with a ratio of $60-95 \%$ (3). Renal colic, characterized by nausea-vomiting that accompanies sudden flank pain and lower urinary tract symptoms that may accompany it, significantly affects the quality of life.

A significant portion of ureteral stones can fall spontaneously. Follow-up with medical treatment of newly diagnosed ureteral stones less than $10 \mathrm{~mm}$ is a recommended treatment alternative. In recent years, spontaneous passage anticipation and medical expulsive therapy (MET) have been added to the European Urological Association urolithiasis and the American Urological Association (AUA) ureteral stone guidelines. In these guidelines, MET is recommended as an initial treatment for ureteral stones smaller than $10 \mathrm{~mm}$ (4).

Treatment options in ureteral stones are 3 main groups: MET, ureteroscopy (URS) and shock wave lithotripsy (SWL). MET is a lower-cost active observation option that can save administered patients from interventional therapies (URS, SWL) and the complications that these interventions can create. In the MET protocol, patients are followed up to 4-6 weeks by administration of hydration, analgesic (non-steroidal anti-inflammatory drug) and alpha-blocker drugs (mostly tamsulosin). In case of acute renal failure, sepsis, progressive hydronephrosis and uncontrollable pain that develops despite treatment in follow-up of patients, or if spontaneous passage does not occur after 4-6 weeks, the interventional treatment stage is switched (4).

Spontaneous passage cannot be achieved in all patients given MET. The most important predictive parameters in this regard are the size of the stone $(<5 \mathrm{~mm},>5 \mathrm{~mm}$ ) and its localization (proximal, mid, distal). According to AUA, $68 \%$ of $<5 \mathrm{~mm}$ stones; $47 \%$ of $>5 \mathrm{~mm}$ stones observed spontaneous passages (5). In recent years, studies have been published showing that biochemical inflammation factors can predict spontaneous passage (6-8). In this study, we aimed to present the role of biochemical inflammation factors [serum white blood cell (WBC), C-reactive protein (CRP), sedimentation, mean platelet volume (MPV), neutrophil/ lymphocyte ratio (NLR), procalcitonin and urine WBC, bacteria] in predicting spontaneous passage in ureteral stones between 5-10 $\mathrm{mm}$ in size in line with statistical analysis.

\section{METHODS}

This prospective observational case-control study was conducted in patients who presented to our outpatient clinic between August 2016 and November 2016 and were diagnosed with ureteral stones, after ethics committee approval (decision no: 05/2016, date: 27.01 .2021$)$ and patient consent. The case group included 54 patients aged 20-60 years with an attack of renal colic and with a single ureteral stone of $5-10 \mathrm{~mm}$ in non-contrast computed tomography (CT) imaging.

Multiple stones, stone tract after SWL or URS, bilateral ureteral stones, solitary kidney, contralateral atrophic kidney, severe hydronephrosis, symptomatic urinary tract infection, signs of acute renal failure, congenital ureteral anomaly, history of ureteral stricture or reconstructive ureter surgery history, patients who were started on anti-inflammatory and/or antibiotic therapy for existing ureteral stones were not included. Exclusion criteria were active infectious disease, chronic inflammatory disease (ulcerative colitis, rheumatoid arthritis, ankylosing spondylitis, etc.), active neoplasia, cardiovascular disease, obesity, diabetes mellitus, thyroid disease or previous thyroid surgery, immunosuppression or immunosuppressive therapy.

In the control group, 33 healthy volunteers between the ages of 20-60, who had no history of stone disease, no chronic or active disease, whose socio-demographic characteristics were similar to the case group were included. Age, gender, body mass index (BMI), smoking habits, chronic diseases, drug allergies, history of stones (stone reduction, stone surgery or SWL treatment) were questioned and recorded during the first examination of the patients. The degree of pain was noted using the visual analog scale (VAS) score. A patient registration form containing patient socio-demographic information, laboratory results, procalcitonin results, imaging data and control records created during followup was completed for all cases. All forms were then registered using Microsoft ${ }^{\circledR}$ Excel $^{\circledR}$.

Case and control groups $(n=87)$ were evaluated with complete blood stripping, CRP, sedimentation, serum procalcitonin, complete urinalysis and ICAB (urine culture antibiogram). WBC, NLR, MPV, red cell distribution width (RDW) values were noted in the complete blood count.

Leukocyturia and bacteriuria were recorded in the complete urinalysis. Presence and degree of hyphronephrosis of the case group were evaluated ultrasonographically. The serum obtained centrifuging the $5 \mathrm{~mL}$ blood sample taken during the first examination was kept until the day the procalcitonin kit will be used. It was stored $-20{ }^{\circ} \mathrm{C}$. Biovendor ${ }^{\circledR}$ (Czech Republic), Human Procalcitonin ELISA (RD191006200R) measurement kit was used for procalcitonin measurement. The serums studied by the Biotek Elx-800 microplate reader device were measured using the Biotek brand Gen5 software program. CT scans ( $n=54)$ taken at University of Health Sciences Turkey, Gaziosmanpaşa Training and Research Hospital were performed using Infiniti ${ }^{\circledR}$ software over the hospital Picture-Archiving and Communication 
System; in the axial and coronal sections, 1.5 and $5 \mathrm{~mm}$ sections were measured and recorded by a single physician. The side of the stone (right/left), location (proximal, mid, distal), size (measurement of the longest segment), area (width $\mathrm{x}$ height) and degree of hydronephrosis were noted using a spiral CT of the entire abdomen without contrast, in which patients received a diagnosis of ureteral stones. In determining the localization of the stone, the section up to the upper border of the sacroiliac joint was determined as the proximal urethra, the section extending along the sacroiliac joint was determined as the mid urethra, and the section from the lower border of the sacroiliac joint to the bladder was determined as the distal urethra. When calculating the size of the stone, coronal and axial images in cross-sectional imaging were also used. Patients who did not have indications for interventional treatment received monitoring by starting MET. For MET, patients were prescribed one diclofenac sodium $75 \mathrm{mg} /$ day (if necessary) and one tamsulosin $0.4 \mathrm{mg} /$ day. In addition, an average daily fluid intake of 2-3 liters was recommended. Patients who were started on MET were called to outpatient controls every two weeks, except for emergencies. During the control of the outpatient clinic, it was questioned whether the patients had passed the stone or not, whether they applied to the emergency department due to renal colic during this treatment period, and their VAS score. In addition, the presence of progressive hydronephrosis was checked with ultrasonography (USG). Among those who stated that they could not pass the stone, the presence of the stone was confirmed by Doppler USG in the second and fourth weeks in those with opaque stones, and in the fourth week of non-opaque non-contrast abdominal CT. At the end of the study, those who could not drop the stone passage (-); those who dropped the stone were grouped as passage (+).

\section{Statistical Analysis}

Mean, standard deviation, median, lowest, highest, frequency and ratio values were used in the descriptive statistics of the data. The distribution of variables was measured by the KolmogorovSmirnov test. The Mann-Whitney $U$ test was used in the analysis of quantitative independent data. Chi-square test was used in the analysis of qualitative independent data, Fisher's Exact test was used when chi-square test conditions were not met. Effect level and cut-off values were investigated using the receiver operating characteristic curve. SPSS 22.0 program was used in the analyses and $p<0.05$ was considered statistically significant.

\section{RESULTS}

At the end of the study, 30 patients (55.5\%) were able to pass ureteral stones, it was found that 24 patients (45\%) could not reduce it. During the follow-up period, none of the patients had findings that required interventional treatment such as fever, persistent and uncontrollable renal colic attacks, progressive hydronephrosis and renal failure. When the patients in the case and control groups were compared in terms of age, gender distribution, BMI value, smoking rate and stone surgery history, no significant difference was found. Considering the rate of extracorporeal SWL and stone- passing history, there was a significant increase in the case group compared to the control group ( $p<0.05$ ) (Table 1).

Laboratory values were not significantly different between both groups in terms of WBC value, bacteriuria rate and CRP value, while RDW value, NLR value, leukocyturia rate, sedimentation value and procalcitonin value were significantly higher in the case group than in the control group ( $p<0.05$ ) (Table 2).

Mean age was calculated (35.8 \pm 9.3$)$ in the group with passage (-); and $(38 \pm 10.9)$ in the group with passage (+). BMI was calculated $(26.4 \pm 4.7)$ in the group with passage (-); and $(26.5 \pm 3.6)$ in the group with passage (+). Compared statistically, no significant differences were found between the age, gender distribution, $\mathrm{BMI}$, and smoking rates of patients in the group with and without a passage (Table 3).

Patients in the group with and without passages did not have statistically significant differences in terms of kidney stone reduction (36.7\%/37.5\%), SWL history (12.5\%/16.7\%) and stone surgery history (8.3\%/6.7\%). There were no statistically significant differences in stone size $(6.5 \pm 1.4 \mathrm{~mm}$ vs $7 \pm 1.2 \mathrm{~mm})$, stone area $\left(36.4 \pm 12.9 \mathrm{~mm}^{2}\right.$ vs $\left.37.5 \pm 10.3 \mathrm{~mm}^{2}\right)$, primary/secondary distribution and laterality in patients in the group with and without passages. However, compared to the non-passage group, the localization rate of the stone to the distal urethra in the passage group was statistically significant $(70 \%$ vs $37.5 \%)(p<0.05)$ (Table 3$)$.

No statistically significant difference was found between the two groups with and without a passage; in terms of WBC value (9.1 \pm 2.4 vs $8.4 \pm 2.3)$, RDW value (15.4 \pm 1.5 vs $15.5 \pm 2.4$ ), NLR value $(2.9 \pm 1.7$ vs $2.8 \pm 1.7)$, MPV value $(8.5 \pm 1.3$ vs $8.7 \pm 0.6)$, CRP value $(11.5 \pm 15.4$ vs $9.8 \pm 8.2)$, sedimentation rate $(14.7 \pm 11.7$ vs $11.8 \pm 7.0)$, bacteriuria rate (6.7\% vs $0 \%)$, and hydronephrosis grade. However, procalcitonin level $(207 \pm 145.1 \mathrm{pg} / \mathrm{mL}$ vs $132.7 \pm 28.1 \mathrm{pg} / \mathrm{mL})$ and leukocyturia rate $(58.3 \%$ vs $20 \%)$ were significantly higher in the non-passage group $(p<0.05)$ (Table 4).

In the differentiation of patients with and without passage, the procalcitonin value [area under the curve 0.805 (0.687-0.923)] and the procalcitonin $160 \mathrm{pg} / \mathrm{mL}$ cut-off value [area under the curve $0.788(0.658-0.917)]$ was found to be significant. Sensitivity was $86.7 \%$, specificity was $70.8 \%$, positive prediction was $78.8 \%$, and negative prediction was $81.0 \%$ (Table 5) (Figure 1).

When the initial VAS pain score was compared, there was no significant difference between the two groups, while the $2^{\text {nd }}$ week VAS pain score of the non-passage group was significantly higher than the passage group $(3.7 \pm 2.4$ vs $2.7 \pm 1.8)(p<0.05)$. Similarly, the $4^{\text {th }}$ week VAS pain score of the group without passage was significantly higher than the group with passage $(3.0 \pm 1.8$ vs $0.8 \pm 1.0)(p<0.05)($ Table 6).

\section{DISCUSSION}

In recent studies, the probability of spontaneous passage of ureteral stones is $71-100 \%$ in $<5 \mathrm{~mm}$ stones; it has been reported that it is $25-46 \%$ in stones between $5-10 \mathrm{~mm}$, and the probability of spontaneous passage within 40 days of ureteral stones with a 
diameter of $<4 \mathrm{~mm}$ is $95 \%(5,9,10)$. Demehri et al. (11) reported that spontaneous passage was seen in $89.9 \%$ of stones $<5 \mathrm{~mm}$, $63.4 \%$ of stones with a size of $5-10 \mathrm{~mm}$, and only $9.1 \%$ of stones with a size $>10 \mathrm{~mm}$. Chau et al. (12) reported that spontaneous passage of ureteral stones between $5-10 \mathrm{~mm}$ was $50 \%$ and $81.8 \%$ in the control group given medical expulsive therapy. In our study, the spontaneous passage rate after 4 weeks of follow-up in patients with a stone size of $5-10 \mathrm{~mm}$ and undergoing medical expulsive therapy was calculated as $55.5 \%$.

Factors that increase the likelihood of spontaneous passage in ureteral stones are generally known as the size of the stone $<5 \mathrm{~mm}$, distal placement, lack of hydronephrosis, while many studies have recently been published on these factors. In a study conducted by Ahmed et al. (13), factors that increase the likelihood of spontaneous passage in ureteral stones $<10 \mathrm{~mm}$ were listed as less than $<5 \mathrm{~mm}$ in size, distal placement, serum WBC height, perinephric fat thickening. Aldaqadossi (14) reported that those with CRP height in distal ureteral stones were less likely to have spontaneous passage.

In another study, Hwang et al. (15) reported URS findings of impacted distal ureteral stones $<5 \mathrm{~mm}$. In this study, luminal stenosis caused by severe mucosal edema was reported in $30 \%$ of the patients, and it was emphasized that mucosal inflammation, which is generally seen in impacted stones, can also be revealed by the tissue rim-sign finding on imaging. Sarica et al. (16) reported that the ureteral wall thickness had a very high effect

Table 1. Comparison of the socio-demographic characteristics of the case and control groups

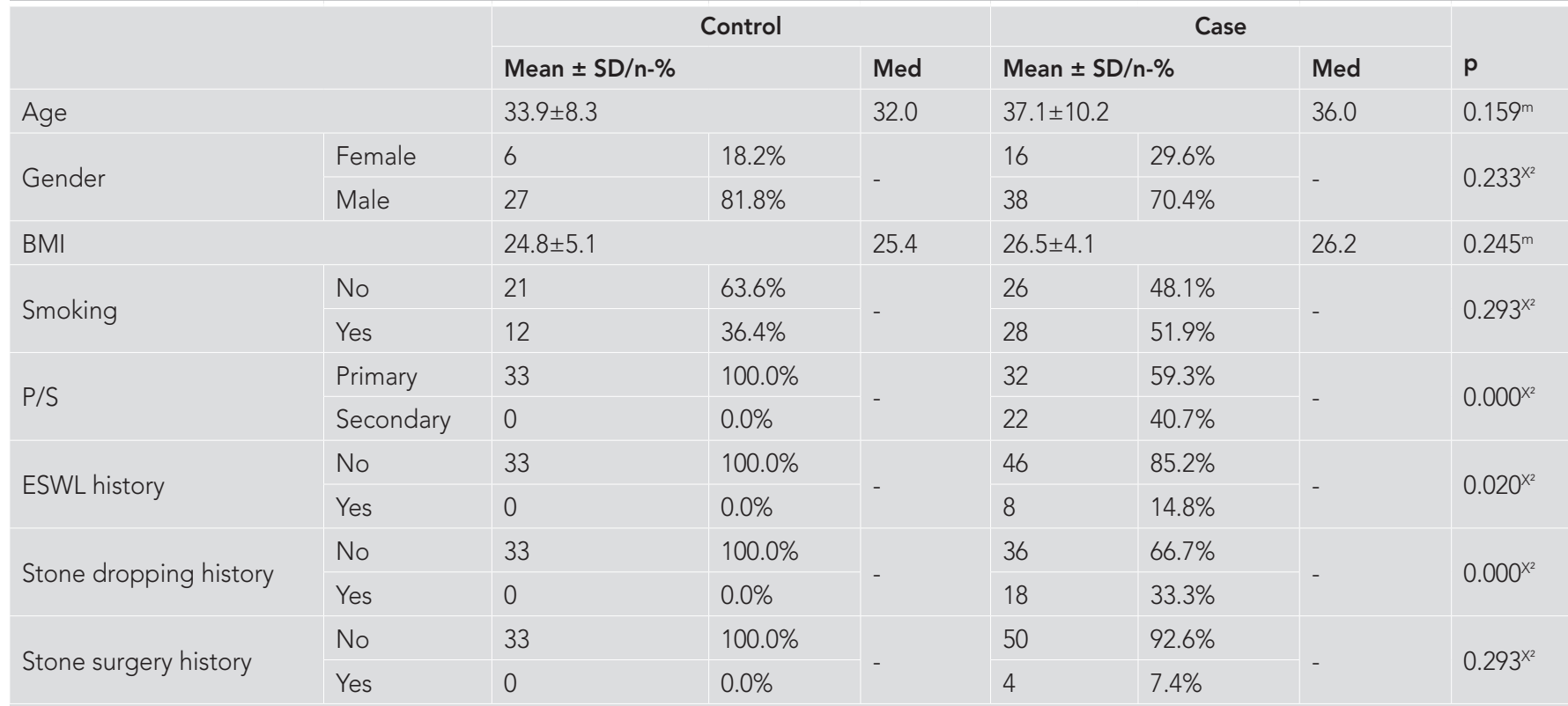

mMann-whitney U test, ${ }^{x^{2}}$ chi-square test. BMI: body mass index, ESWL: extracorporeal shock wave lithotripsy, SD: standard deviation, Med: median, P/S: primary/ secondary

Table 2. Comparison of serum and urinary inflammation markers of case and control groups

\begin{tabular}{|c|c|c|c|c|c|c|}
\hline & & \multicolumn{2}{|c|}{ Control group } & \multicolumn{2}{|c|}{ Case group } & \multirow{2}{*}{$p$} \\
\hline & & Mean $\pm \mathrm{SD} / \mathrm{n}-\%$ & Med & Mean $\pm \mathrm{SD} / \mathrm{n}-\%$ & Med & \\
\hline \multicolumn{2}{|l|}{ WBC } & $8.0 \pm 1.9$ & 7.5 & $8.8 \pm 2.3$ & 8.3 & $0.053^{\mathrm{m}}$ \\
\hline \multicolumn{2}{|l|}{ NLR } & $2.0 \pm 0.3$ & 2.2 & $2.8 \pm 1.7$ & 2.3 & $0.009^{m}$ \\
\hline \multicolumn{2}{|l|}{ MPV } & $8.5 \pm 0.7$ & 8.4 & $8.6 \pm 1.0$ & 8.6 & $0.451^{\mathrm{m}}$ \\
\hline Bacteriuria & Yes & $0 / 0.0 \%$ & - & $2 / 3.7 \%$ & - & $0.524^{x^{2}}$ \\
\hline \multirow{2}{*}{ Leukocyturia } & No & $33 / 100 \%$ & - & $34 / 63.0 \%$ & - & \multirow{2}{*}{$0.000^{x^{2}}$} \\
\hline & Yes & $0 / 0.0 \%$ & - & $20 / 37.0 \%$ & - & \\
\hline \multicolumn{2}{|l|}{ CRP } & $4.0+1.1$ & 3.4 & $10.4 \pm 12.6$ & 4.7 & $0.088^{m}$ \\
\hline \multicolumn{2}{|l|}{ Sedimentation } & $4.2+1.3$ & 4.0 & $13.4 \pm 9.9$ & 11.0 & $0.000^{m}$ \\
\hline
\end{tabular}


on the stone-free rates in impacted proximal ureteral stones that underwent SWL. In this study, the sensitivity of the cut-off value of $3.55 \mathrm{~mm}$ for ureteral wall thickness was reported as $91.7 \%$, the specificity as $77 \%$. In light of this information, we investigated the predictability of spontaneous passage with serum inflammation markers based on the association of impacted ureteral stonemucosal inflammation. As a result of our study, serum WBC, RDW, NLR, MPV, CRP, sedimentation values did not have a role in determining spontaneous passage in patients we followed up with medical expulsive therapy, however, leukocyturia rate and high serum procalcitonin values were statistically significant $(p=0.004, p<0.001)$. We concluded that it reduces the possibility of spontaneous passage. As a result of statistical analysis, we concluded that those whose serum procalcitonin value is less than $160 \mathrm{pg} / \mathrm{mL}$ are more likely to have spontaneous passage. In addition, in parallel with other studies, we found that distal ureteral stones are significantly more likely to be spontaneous passage $(p<0.05)$. We believe that it is important to demonstrate the ability of procalcitonin and leukocyturia to predict passage, unlike other markers.
Procalcitonin is a polypeptide consisting of 116 amino acids with a molecular weight of about 13 kilodaltons. This hormone was first described by Ghillani et al. (17) in 1989 as a precursor of calcitonin, which is produced in the thyroid gland and contains 32 amino acids. Activated calcitonin is produced by proteolytic enzymes in the $\mathrm{C}$-cells of the thyroid. Production of procalcitonin and calcitonin begins with the transcription of the preprocalcitonin precursor containing 141 amino acids. It has been shown that endotoxins increase in sepsis and inflammation, and procalcitonin levels increase in the body shortly after the release of immune mediators (18). Studies have shown that procalcitonin causes significant inhibition of prostaglandin and thromboxane synthesis in lymphocytes in vitro. Inhibition of cyclooxygenase activity has been held responsible for this inhibition (19).

Procalcitonin increases 4-6 hours after endotoxin administration, peaks at 6-8 hours, and plateaus from 12-48 hours due to a half-life of 25-30 hours (20). The value of procalcitonin in the normal population is known as $<0.05 \mathrm{ng} / \mathrm{mL}$. In systemic infections, it can reach levels of $2 \mathrm{ng} / \mathrm{mL}$; in sepsis, it can reach levels of $10 \mathrm{ng} / \mathrm{mL}(21,22)$.

\begin{tabular}{|c|c|c|c|c|c|c|}
\hline & & \multicolumn{2}{|c|}{ Passage (-) } & \multicolumn{2}{|c|}{ Passage (+) } & \multirow{2}{*}{$p$} \\
\hline & & Mean \pm SD/n (\%) & Med & Mean \pm SD/n (\%) & Med & \\
\hline \multicolumn{2}{|l|}{ Age } & $35.8 \pm 9.3$ & 35.0 & $38.0 \pm 10.9$ & 38.0 & $0.381^{m}$ \\
\hline \multirow{2}{*}{ Gender } & Female & $10(41.7 \%)$ & \multirow{2}{*}{ - } & $6(20.0 \%)$ & \multirow{2}{*}{-} & \multirow{2}{*}{$0.083^{x}$} \\
\hline & Male & 14 (58.3\%) & & 24 (80.0\%) & & \\
\hline \multicolumn{2}{|l|}{ BMI } & $26.4 \pm 4.7$ & 26.2 & $26.5 \pm 3.6$ & 26.2 & 0.781 \\
\hline \multirow{2}{*}{ Smoking } & No & $12(50.0)$ & \multirow[t]{2}{*}{-} & $14(46.7 \%)$ & \multirow{2}{*}{-} & \multirow{2}{*}{$0.808^{x_{2}}$} \\
\hline & Yes & $12(50.0)$ & & $16(53.3 \%)$ & & \\
\hline \multirow{2}{*}{$\begin{array}{l}2^{\text {nd }} \text { week passage } \\
4^{\text {th }} \text { week passage }\end{array}$} & & \multirow{2}{*}{ - } & \multirow{2}{*}{ - } & $8(26.7 \%)$ & \multirow{2}{*}{-} & \multirow{2}{*}{ - } \\
\hline & & & & $26(86.7 \%)$ & & \\
\hline \multirow{4}{*}{ Stone dropping history } & No & 15 (62.5\%) & - & 19 (63.3\%) & - & \multirow{4}{*}{$0.950^{x}$} \\
\hline & Yes & $9(37.5 \%)$ & - & $11(36.7 \%)$ & - & \\
\hline & Right & $6(25.0 \%)$ & - & $6(20.0 \%)$ & - & \\
\hline & Left & $3(12.5 \%)$ & - & $5(16.7 \%)$ & - & \\
\hline \multirow{2}{*}{ ESWL history } & No & 21 (87.5\%) & - & 25 (83.3\%) & - & \multirow{2}{*}{$0.668^{x^{2}}$} \\
\hline & Yes & $3(12.5 \%)$ & - & $5(16.7 \%)$ & - & \\
\hline \multirow{2}{*}{ Stone surgery history } & No & 22 (91.7\%) & - & 28 (93.3\%) & - & \multirow{2}{*}{$0.816^{x_{-}}$} \\
\hline & Yes & $2(8.3 \%)$ & - & $2(6.7 \%)$ & - & \\
\hline Stone size $(\mathrm{mm})$ & & $7.0 \pm 1.2$ & 7.0 & $6.5 \pm 1.4$ & 6.4 & $0.200^{m}$ \\
\hline Stone area $\left(\mathrm{mm}^{2}\right)$ & & $37.5 \pm 10.3$ & 34.2 & $36.4 \pm 12.9$ & 30.0 & $0.310^{m}$ \\
\hline \multirow{2}{*}{$\mathrm{P} / \mathrm{S}$} & Primary & 15 (62.5\%) & - & $17(56.7 \%)$ & - & \multirow{2}{*}{$0.665^{x_{-}}$} \\
\hline & Secondary & $9(37.5 \%)$ & - & $13(43.3 \%)$ & - & \\
\hline \multirow{2}{*}{ Side } & Right & $10(41.7 \%)$ & - & $12(40.0 \%)$ & - & \multirow{2}{*}{$0.901^{x}$} \\
\hline & Left & 14 (58.3\%) & - & 18 (60.0\%) & - & \\
\hline \multirow{3}{*}{ Localization } & Proximal & $7(29.2 \%)$ & - & $2(6.7 \%)$ & - & \multirow{3}{*}{$0.029^{x}$} \\
\hline & Mid & $8(33.3 \%)$ & - & $7(23.3 \%)$ & - & \\
\hline & Distal & $9(37.5 \%)$ & - & 21 (70.0\%) & - & \\
\hline
\end{tabular}

${ }^{m} M a n n-W h i t n e y ~ U$ test, ${ }^{{ }^{2}}$ chi-square test, SD: standard deviation, BMI: body mass index, ESWL: extracorporeal shock wave lithotripsy, Med: median, P/S: primary/ secondary 
Table 4. Statistical comparison of stone size, area, side and localization of the case group in the group with and without passage

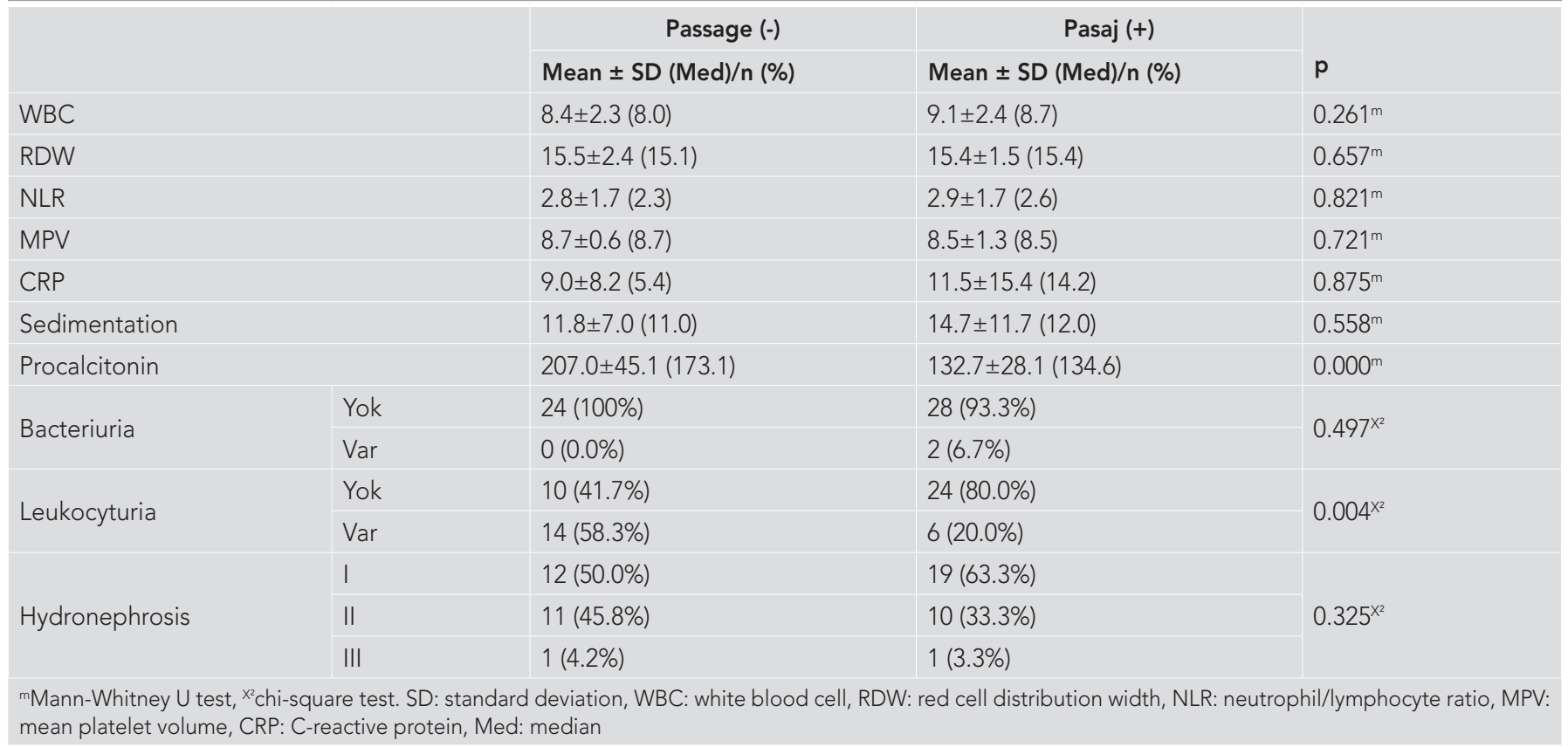

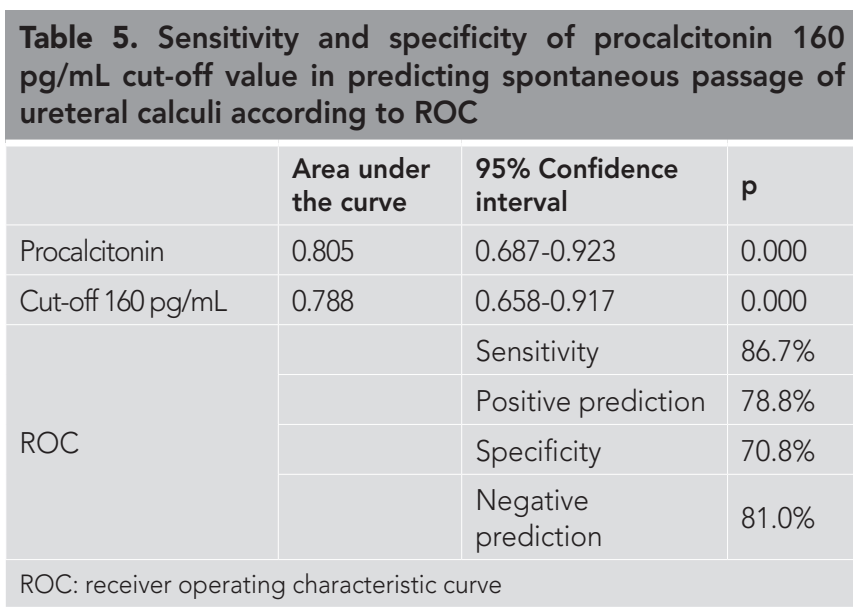

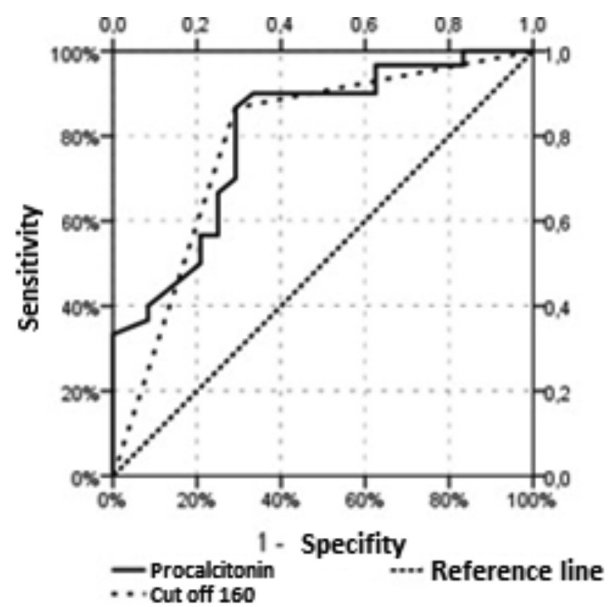

Figure 1. ROC for procalcitonin $160 \mathrm{pg} / \mathrm{mL}$ cut-off value in predicting spontaneous passage $R O C$ : receiver operating characteristic curve
In our study, the cut-off value of procalcitonin in estimating the passage was calculated as $160 \mathrm{pg} / \mathrm{mL}(=0.16 \mathrm{ng} / \mathrm{mL})$. The average value of the non-passage group was $207+145.1 \mathrm{pg} / \mathrm{mL}$ and the non-passage group was $132.7+28.1 \mathrm{pg} / \mathrm{mL}$. We think that the elevation of procalcitonin in the non-passage group is associated with the excess of mucosal inflammation. The excess of this mucosal inflammation may have increased the impaction of the stones in the future and made their passage difficult. Between the two groups; The statistically significant difference in the second week (3.7/2.7) and fourth week (3.0/0.8) VAS scores may also explain the difference in mucosal inflammation and edema.

Procalcitonin is used in the early and reliable diagnosis of sepsis, in determining the severity of sepsis, in the differential diagnosis of acute pancreatitis infection and sterile necrosis, in autoimmune diseases, in differentiating acute organ rejection from bacterial infection, as an early indicator of post-operative bacterial or septic infectious complications, and in the follow-up of neutropenic patients after chemotherapy $(18,23)$. In addition, studies have been published in recent years indicating that procalcitonin can detect relapses in patients with chronic prostatitis, that the infection rate in obstructed ureteral stones and the elevation of procalcitonin are correlated, that it can detect the severity of inflammation in patients with cholecystitis, and its importance in the diagnosis of bacterial arthritis (24-27). In our study, it was investigated whether procalcitonin values were effective in the decision to follow-up of patients diagnosed with ureteral stones.

When the study groups were compared, it was revealed by statistical analysis that the patients were homogeneous in terms of socio-demographic characteristics (age, gender distribution, $\mathrm{BMI}$, smoking) and features that may cause anatomical stenosis (history of stone loss, open ureterolithotomy, URS, SWL). Procalcitonin elevation and the presence of leukocyturia were 
Table 6. Comparison of the group with and without passage according to baseline, $2^{\text {nd }}$ and $4^{\text {th }}$ week control VAS scores

\begin{tabular}{|c|c|c|c|c|c|}
\hline & \multicolumn{2}{|c|}{ Passage (-) } & \multicolumn{2}{|c|}{ Passage (+) } & \multirow[b]{2}{*}{$p$} \\
\hline & Ortalama \pm SD & Med & Ortalama \pm SD & Med & \\
\hline \multicolumn{6}{|c|}{ VAS pain score } \\
\hline $2^{\text {nd }}$ week & $3.7 \pm 2.4$ & 4.0 & $2.7 \pm 1.8$ & 3.0 & $0.049^{m}$ \\
\hline $4^{\text {th }}$ week & $3.0 \pm 1.8$ & 3.0 & $0.8 \pm 1.0$ & 0.0 & $0.000^{m}$ \\
\hline
\end{tabular}

found to be statistically significantly higher in the two groups, which were homogeneous with all their features except localization distribution. We think that finding a statistically significant cut-off value of $160 \mathrm{pg} / \mathrm{mL}$ for procalcitonin in our study is promising. We believe that procalcitonin can be effective in the decision of follow-up or interventional treatment of patients, especially in ureteral stones with a size of 5-10 mm, which are less likely to have spontaneous passage compared to stones $<5 \mathrm{~mm}$.

In a study conducted by Ahmed et al. (13), it was reported that the number of leukocytes in urine microscopy did not differ statistically significantly in the group with and without passages. In one study, it was noted that treatment with Rowatinex ${ }^{\circledR}$ after SWL is an effective treatment for getting rid of residual fragments, and leukocyturia is significantly reduced after Rowatinex ${ }^{\circledR}$ use (28). In our study, leukocyturia was observed in $20 \%$ of the group with passage and in $58.3 \%$ of the group without passage, and a statistically significant difference was found between them $(p=0.004)$. We think that the higher rate of sterile leukocyturia seen in urine analysis in the non-passage group indicates excess mucosal inflammation.

\section{Study Limitations}

We think that the small number of our cohort and the lack of repeated measurements are limitations. We think that the large number of case groups may enable analysis by dividing them into subgroups (proximal, mid and distal), especially according to the localization of ureteral stones at the initial diagnosis stage, and the analysis of these homogeneous groups may increase the value of the study.

\section{CONCLUSION}

In recent years, studies have been conducted that predict that biochemical inflammation factors may be one of the predictive factors in predicting spontaneous passage. In our study, procalcitonin levels were used for the first time to predict the passage of ureteral stones between $5-10 \mathrm{~mm}$, and it was found that the height of the level may be a factor that complicates the passage. Our findings suggest that procalcitonin level measurement may be possible to take place in daily urology practice after studies with higher series. In addition, our findings suggest that the presence of leukocyturia in patients with ureteral stones may be a factor that complicates spontaneous passage.
Ethics Committee Approval: This study was approved by the Clinical Research Ethics Committee of Gaziosmanpaşa Training and Research Hospital (decision no: 05/2016, date: 27.01.2021).

Informed Consent: Informed consent was obtained from the patients.

Peer-review: Externally peer-reviewed.

Author Contributions: Surgical and Medical Practices - N.C.Ç.; Concept - N.C.Ç., B.A., B.N.; Design - B.A., Ö.A., B.N.; Data Collection and/or Processing - N.C.Ç., Ö.A.; Analysis and/or Interpretation - B.A., M.B.C.B., B.N.; Literature Search - N.C.Ç., M.B.C.B.; Writing - N.C.Ç., Ö.A.

Conflict of Interest: The authors have no conflict of interest to declare.

Financial Disclosure: The authors declared that this study has received no financial support.

\section{REFERENCES}

1. Jungers P, Joly D, Barbey F, Choukroun G, Daudon M. ESRD caused by nephrolithiasis: prevalence, mechanisms, and prevention. Am J Kidney Dis 2004; 44: 799-805.

2. Pak CY. Kidney stones. Lancet 1998; 351: 1797-801.

3. Tamm EP, Silverman PM, Shuman WP. Evaluation of the patient with flank pain and possible ureteral calculus. Radiology 2003; 228: 319-29.

4. Türk C, Petř́k A, Sarica K, Seitz C, Skolarikos A, Straub M, et al. EAU guidelines on diagnosis and conservative management of urolithiasis. Eur Urol 2016; 69: 468-74.

5. Preminger GM, Tiselius HG, Assimos DG, Alken P, Buck AC, Gallucci $\mathrm{M}$, et al; American Urological Association Education and Research, Inc.; European Association of Urology. 2007 Guideline for the management of ureteral calculi. Eur Urol 2007; 52: 1610-31. 6.Sfoungaristos S, Kavouras A, Katafigiotis I, Perimenis P. Role of white blood cell and neutrophil counts in predicting spontaneous stone passage in patients with renal colic. BJU Int 2012; 110: E339-45. doi: 10.1111/j.1464-410X.2012.11014.x.

7. Kim $\mathrm{BH}$. the authors reply: relationship between spontaneous passage rates of ureteral stones less than $8 \mathrm{~mm}$ and serum C-reactive protein levels and neutrophil percentages. Korean J Urol 2013; 54: 889-90.

8. Angulo JC, Gaspar MJ, Rodríguez N, García-Tello A, Torres G, Núñez C. The value of $\mathrm{C}$ - reactive protein determination in patients with renal colic to decide urgent urinary diversion. Urology 2010; 76: 301-6.

9. Skolarikos A, Laguna MP, Alivizatos G, Kural AR, de la Rosette JJ. The role for active monitoring in urinary stones: a systematic review. J Endourol 2010; 24: 923-30.

10. Miller OF, Kane CJ. Time to stone passage for observed ureteral calculi: a guide for patient education. J Urol 1999; 162: 688-90; discussion 690-1.

11. Demehri S, Steigner ML, Sodickson AD, Houseman EA, Rybicki FJ, Silverman SG. CT- based determination of maximum ureteral stone area: a predictor of spontaneous passage. AJR Am J Roentgenol 2012; 198: 603-8.

12. Chau LH, Tai DC, Fung BT, Li JC, Fan CW, Li MK. Medical expulsive therapy using alfuzosin for patient presenting with ureteral stone less than $10 \mathrm{~mm}$ : a prospective randomized controlled trial. Int J Urol 2011; 18: 510-4.

13. Ahmed AF, Gabr AH, Emara AA, Ali M, Abdel-Aziz AS, Alshahrani S. Factors predicting the spontaneous passage of a ureteric calculus of $\leq 10$ mm. Arab J Urol 2015; 13: 84-90.

14. Aldaqadossi HA. Stone expulsion rate of small distal ureteric calculi could be predicted with plasma C-reactive protein. Urolithiasis 2013; 41: 235-9. 
15. Hwang E, Kim YH, Yuk SM, Sul CK, Lim JS. Factors that predict spontaneous passage of a small distal ureteral stone $<5 \mathrm{~mm}$. J Endourol 2010; 24: 1681-5.

16. Sarica K, Kafkasli A, Yazici Ö, Çetinel AC, Demirkol MK, Tuncer M, et al. Ureteral wall thickness at the impacted ureteral stone site: a critical predictor for success rates after SWL. Urolithiasis 2015; 43: 83-8.

17. Ghillani PP, Motte P, Troalen F, Jullienne A, Gardet P, Le Chevalier T, et al. Identification and measurement of calcitonin precursors in serum of patients with malignant diseases. Cancer Res 1989; 49: 6845-51.

18. Meisner M. Procalcitonin: a new innovative infection parameter. In: Meisner M, editor. Biochemistry. Stuttgart: Brahms Diagnostica; 2000. p.15

19. Oczenski W, Fitzgerald RD, Schwarz S. Procalcitonin: a new parameter for the diagnosis of bacterial infection in the peri-operative period. Eur $J$ Anaesthesiol 1998; 15: 202-9.

20. Demirdağ K, Özden M, Gödekmerdan A, Cihangiroğlu M, Kalkan A. Sepsis olgularında prokalsitonin, TNF- ve C-reaktif protein düzeylerinin değerlendirilmesi. Klimik Derg 2003; 16: 21-4.

21. Braithwaite SS. Procalcitonin: new insights on regulation and origin. Crit Care Med 2000; 28: 586-88.

22. Claeys R, Vinken S, Spapen H, ver Elst K, Decochez K, Huyghens L, et al. Plasma procalcitonin and $\mathrm{C}$-reactive protein in acute septic shock: Clinical and biological correlates. Crit Care Med 2002; 30: 757-62.
23. Becker KL, Snider R, Nylen ES. Procalcitonin assay in systemic inflammation,infection, and sepsis: clinical utility and limitations. Crit Care Med 2008; 36: 941-52.

24. Çakıroğlu B, Eyyüpoğlu E, Balcı MBC, Hazar Aí, Uyanık BS, Doğan AN. The evaluation of the procalcitonin levels in chronic prostatitis patients. Nobel Med 2016; 12: 60-5.

25. Yuzbasioglu Y, Duymaz H, Tanrikulu CS, Halhalli HC, Koc MO, Tandoğan $M$, et al. Role of procalcitonin in evaluation of the severity of acute cholecystitis. Eurasian J Med 2016; 48: 1621-6.

26. Martinot $M$, Sordet $C$, Soubrier M, Puéchal X, Saraux A, Lioté F, et al. Diagnostic value of serum and synovial procalcitonin in acute arthritis: a prospective study of 42 patients. Clin Exp Rheumatol 2005; 23: 303-10.

27. Papagiannopoulos D, Whelan P, Ahmad W, Rybak J, Hota B, Deane L, et al. Procalcitonin is a strong predictor of urine culture results in patients with obstructing ureteral stones: A prospective, pilot study. Urol Ann 2016; 8: 277-80.

28. Alyaev YG, Rudenko VI, Perekalina AN, Kraev IG, Inoyatov ZS. Plantderived terpenes in treating patients with urolithiasis. Urologiia. 2016; (Suppl 2): 103-10. (Russian) 